\section{ULOGA, STANDARDI I KOMPETENCIJE SOCIJALNIH RADNIKA U PALIJATIVNOJ SKRBI}

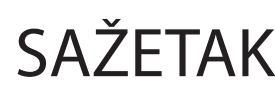

Društvene promjene dovele su do povećane potrebe za palijativnom skrbi u svijetu. Taj pristup potiče interdisciplinarni rad i plodno tlo za razvoj profesije socijalnog rada. Prvi korak u tom razvoju jest postavljanje ključnih standarda i kompetencija čime socijalni rad potvrđuje svoju potrebitost i potencira svoj razvoj. Socijalni radnici posjeduju znanja i vještine za rad u raznim područjima palijativne skrbi te u nju donose znanja, vještine i kompetencije koje tvore ulogu socijalnog radnika u sveobuhvatnom pristupu palijativne skrbi. Sagledavajući suvremene teorijske koncepte, osnovne postavke prakse socijalnog rada, osnovne postavke palijativne skrbi, te vještine i kompetencije socijalnih radnika, stvoren je svojevrsni vodič socijalnim radnicima u palijativnoj skrbi, koji im može pomoći u njihovom radu na tom još uvijek novom području prakse. Kroz ovaj rad izloženi su osnovni standardi, kompetencije te uloga socijalnih radnika u palijativnoj skrbi kao temelj za daljnji rad na istima.

1 Izv. prof. dr. sc. Ana Štambuk, socijalna radnica, e-mail: astambuk@pravo.hr

2 Tamara Obrvan, magistra socijalnog rada, e-mail: tamara.obrvan@gmail. com
Pregledni članak

Primljeno: listopad, 2016.

Prihvaćeno: ožujak, 2017.

UDK 364.62:616-082

D0I 10.3935/ljsr.v24i1.142

Ana Štambuk'

Sveučilište u Zagrebu

Pravni fakultet

Studijski centar socijalnog rada

Tamara Obrvan ${ }^{2}$

Dom za starije osobe »Centar«

Ključne riječi:

palijativna skrb, socijalni radnici, standardi, kompetencije, uloga. 


\section{UVOD}

Socijalni radnici uključeni su u palijativnu skrb od njenih početaka. Cicely Saunders, utemeljiteljica modernog hospicijskog pokreta, bila je socijalna radnica, kasnije i liječnica te je isticala važnost holističkog pristupa pacijentu. Socijalni radnici pridonose palijativnoj skrbi i skrbi na kraju života svojim kompetencijama koje imaju za cilj: poboljšanje kvalitete života pacijenata (Štambuk, 2011.); promicanje pravde i mogućnosti svih pacijenata i njihovih obitelji na pristup adekvatnoj skrbi; preuzimanje multidimenzionalne uloge kao kliničara, nastavnika, znanstvenika, odvjetnika, voditelja u zajednici i analitičara (Štambuk, 2013.). Znanje, vještine i vrijednosti socijalnih radnika određuju njihov profesionalni rad. Socijalni rad i palijativna skrb imaju bitne poveznice s palijativnom medicinom - holistički pristup zdravlju, poticanje individualnih izbora, fokusiranje na snage umjesto na bolest. Unutar palijativne skrbi ne sagledavaju se samo fizički, nego socijalni, psihološki i duhovni problemi umiruće osobe i njene obitelji, kao i zajednice u kojoj se nalazi (Reith i Payne, 2009.). Teorijski pristup koji se nalazi u pozadini ovakvog sagledavanja problematike palijativne skrbi je biopsihosocijalno-duhovni model. Puchalski i sur. (2009.) navode osnovne značajke tog modela: bolest zahvaća cijelu osobu sa svim njenim dimenzijama, bolest narušava više od odnosa unutar ljudskog organizma (narušava obitelj i radna mjesta te razbija postojeće obrasce suočavanja s problemima kao i odnos prema svetom), u svrhu funkcionalnog liječenja trebaju se procijeniti i sagledati svi navedeni aspekti te se isti trebaju uključiti u plan tretmana pacijenta.

\section{ULOGA SOCIJALNIH RADNIKA U PALIJATIVNOJ SKRBI}

Sheldon (2000.) ističe šest dimenzija važnih za ulogu socijalnog radnika u palijativnoj skrbi:

1. obiteljski fokusiran - usmjerenost na komunikaciju i probleme u odnosima

2. utječe na okolinu - praktična pomoć i veze

3. član je tima - poštuje granice i spreman na suradnju

4. upravlja i prepoznaje anksioznost - u obitelji, kod kolega u timu, kod sebe

5. vrijednosti i vrednovanje - neosuđujuće, usmjereno na osnaživanje, antidiskriminatorno

6. znanje i rad s granicama - dobra procjena i otvorena komunikacija.

Svakodnevne aktivnosti socijalnog radnika razlikovat će se od države do države, ali potreba za palijativnom skrbi svugdje je prepoznata. Socijalni radnici u partnerstvu s pacijentom (korisnikom) i njegovom obitelji osiguravaju da su njihove

\section{0 članci}




\section{A. Štambuk, T. Obrvan: Uloga, standardi i kompetencije socijalnih radnika u palijativnoj skrbi}

želje i potrebe zadovoljene kada god je to moguće. Ključne vještine i vrijednosti pristupa koji ne osuđuje, koristeći dobre komunikacijske vještine, razvoj povjerenja i uspostavljanje dobre radne atmosfere, omogućuju promjenu. Situacije u kojima socijalni radnici interveniraju su kompleksne, a etičke i moralne dileme vrlo česte. Unutar osjetljivog, promjenjivog i kompleksnog okruženja palijativne skrbi, socijalni radnici trebaju ostvariti dobar odnos sa svim dionicima skrbi.

Socijalni radnici trebaju preispitivati svoje stavove i predrasude te razumjeti potrebe obitelji kao sustava, koje mogu biti u suprotnosti s potrebama pojedinca. Stoga je osnovna uloga socijalnih radnika u palijativnoj skrbi izgradnja dobrog odnosa s korisnikom. U slučajevima gdje socijalni radnik ostvari dobar odnos s korisnikom, preporučuje se zadržati i kontakt s obitelji (Parry, 2001.) što se može postići održavanjem kontakata telefonom i zakazivanjem redovitih sastanaka s obitelji (Mulkerin, 2011.). Vrlo je važno uspostaviti jasnu i dobru komunikaciju s primarnim njegovateljem, tj. osobom koja je u bliskom odnosu s korisnikom, poznaje njegove želje i stavove te može pomoći timu palijativne skrbi u planiranju intervencija kao i u izgradnji odnosa s korisnikom. Socijalni radnik pomaže obitelji da poštuje, razumije i zastupa interese svih uključenih osoba, ali na način da ne ugrožava odluke koje je donio sam korisnik (Reith i Payne, 2009.). To je važno radi održavanja obiteljske ravnoteže u situaciji umiranja, kada treba omogućiti dostojanstven odlazak. U tom razdoblju članovi obitelji mogu se osjećati napušteno, nesigurno, prestravljeno i/ili ljuto, no ako ih socijalni radnik sasluša s empatijom i adekvatno odgovori na njihove intenzivne osjećaje - to može biti vrlo produktivno kako za obitelj, tako i za korisnika, a na kraju i za samog socijalnog radnika. U nekim situacijama socijalni radnik može povezati umiruću osobu s članovima obitelji s kojima se tijekom života udaljila i nisu kontaktirali (Parry, 2001.).

U suočavanju s neizlječivom bolesti i umiranjem, obitelj, a pogotovo neformalni njegovatelji, nalaze se pod visokostresnom situacijom. Stoga Harding i Leam (2005.) ističu da u posljednjim danima, neposredno prije smrti, potrebe obitelji mogu nadići potrebe korisnika. Neke od multidimenzionalnih potreba neformalnih njegovatelja korisnika koje autori navode su psihološka podrška, informiranje, nošenje s umorom, financijska podrška i odmor. Kako bi zadovoljili te potrebe, socijalni radnici mogu njegovateljima omogućiti pristup službama podrške te pružiti emocionalnu i psihološku pomoć. Poduzete intervencije trebaju povećati moral, samopouzdanje, nošenje sa situacijom i kontrolu nad situacijom od strane njegovatelja, a smanjiti anksioznost i depresiju. Socijalni radnici trebaju biti spremni na provođenje: psihoedukacijskih intervencija, obiteljskih sastanka (Glajchen, 2011.) kao i treninga vještina (McMillan i sur., 2006.).

Rad s obitelji nastavlja se i tijekom razdoblja tuge i žalovanja. Osim grupa za podršku ili žalovanje, postoji još cijeli niz intervencija u kojima socijalni radnik može 
sudjelovati u tom razdoblju: podrška i savjetovanje, psihoterapija (psihodinamski i kognitivno-bihevioralni pristup) te sistemski orijentirane intervencije s osobama ili obiteljima u žalovanju (Forte i sur., 2004.). Kao zasebnu kategoriju, Forte i sur. (2004.) navode sistemski orijentirane intervencije koje mijenjaju način na koji je zdravstveni sustav u interakciji s pacijentima, obiteljima i prijateljima prije smrti, vodeći se temeljnom idejom da interakcije doživljene od strane voljenih prije smrti mogu promijeniti proces tugovanja. Vrijednost takvih intervencija počiva na širim promjenama koje mogu donijeti dobrobit ne samo onima na koje su se konkretno primijenile, već i za buduće korisnike palijativne skrbi.

Intervencije socijalnog rada s njegovateljima i članovima obitelji mogu se pružati jedan-na-jedan, no ekstremni stres koji prolaze može se efektno suzbiti nalaženjem s drugima koji dijele sličnu situaciju (NICE, 2004., prema Reith i Payne, 2009.). Članovi obitelji i njegovatelji koji su u procesu žalovanja mogu iz grupa podrške dobiti puno dobroga. Istraživanja pokazuju da se neki od najbitnijih pozitivnih procesa tugovanja pojavljuju samo, ili u najboljem svjetlu, tek u grupnom radu (Sutton i Liechty, 2004., prema Rieth i Payne, 2009.). Grupe za podršku mogu pomoći članovima da podijele svoje iskustvo s drugima (Parry, 2001.), što pruža ventilaciju, ali i omogućava pronalaženje novih načina rješavanja problema na koje nailaze, kao i podršku od strane osoba koje se nalaze u sličnoj situaciji.

\section{Kompetencije i standardi socijalnih radnika u palijativnoj skrbi}

Kada govorimo o standardima određene profesije, govorimo o etičkim smjernicama, pravilima ponašanja i uobičajenim praksama koje reguliraju legalne, medicinske i druge profesije (Bussiness Dictionary, 2014.). S druge strane, kompetencija je klaster povezanih sposobnosti, obveza, znanja i vještina koje omogućavaju osobi ili organizaciji da učinkovito djeluju na poslu ili situaciji, odnosno dovoljna razina znanja i vještina koja omogućuje nekome djelovanje u određenim situacijama (Bussiness Dictionary, 2014.). Standardi i kompetencije izuzetno su povezani, u toj mjeri da neki autori navode kako je postavljanje kompetencija socijalnog rada imperativ postavljanju standarda (Bosma i sur., 2010.), a potrebne su da bi se osigurala visokokvalitetna usluga socijalnog rada u različitim dijelovima prakse palijativne skrbi i s različitim populacijama, s posebnim naglaskom na kontekst koji nadilazi postavke zdravstvene zaštite, a uključuje prilagodbu na po život opasnu bolest (Gwyter i sur., 2005.). Kompetencije su potrebne na razne načine: mogu se koristiti kao smjernice za profesionalni razvoj i nastavni program kao i za informiranje kolega u interdisciplinarnom timu (Bosma i sur., 2010.). Identificiranjem kompetencija

\section{2 članci}




\section{A. Štambuk, T. Obrvan: Uloga, standardi i kompetencije socijalnih radnika u palijativnoj skrbi}

naglašavamo što je potrebno da bi socijalni radnici pružili kvalitetnu uslugu u palijativnoj skrbi (Gwyter i sur., 2005.). Ne postoji jedan dokument koji bi ih precizno odredio, niti postoji jasna suglasnost u praksi oko kompetencija socijalnih radnika u palijativnoj skrbi. Stoga će u ovom radu biti korišten dokument "Social Work Competencies in Palliative and End-of-life care« (Gwyter i sur., 2005.) čiji su temelji postavljeni na "Social Work Leadership Summit on End-of-Life and Palliative Care" održanom 2002. godine, u kojem su kompetencije navedene detaljno i uz korištenje brojnih izvora. Također, Bosma i sur. (2010.) definiraju kompetencije za socijalne radnike u hospicijskoj palijativnoj skrbi u Kanadi, pružajući izvorište kompetencija socijalnih radnika u palijativnoj skrbi. $U$ drugom dijelu rada čitateljima će se približiti filozofija biopsihosocijalno-duhovnog pristupa u radu s korisnicima koji se temelji na poštovanju ljudskog dostojanstva.

\section{Etika i vrijednosti}

Socijalni rad je profesija koja se temelji na vrijednostima (Reamer, 2013.), a poštovanje etike i vrijednosti socijalnog rada mora biti osnovni standard socijalnog rada u palijativnoj skrbi. Socijalni radnici u palijativnoj skrbi trebaju biti spremni na izazove koji obuhvaćaju evaluaciju etičkih dilema i vrijednosnih sukoba te razmatraju pitanja povezana s religijom, duhovnosti i smislom života (NASW, 2004.). Prepoznavanje i uvažavanje duhovnih potreba korisnika utječe na zdravstvene odluke i na ishode njege, uključujući i kvalitetu života (Štambuk, 2011.). Socijalni radnici trebaju razumjeti načine na koji duhovnost utječe na korisnika te informirati o tome ostale članove tima (NASW, 2004.). Odgovornost je socijalnih radnika pružiti njegu koja je individualizirana i u kojoj su želje, vrijednosti i pogledi korisnika često oprečni željama, vrijednostima i pogledima osoblja, zdravstvenog sustava i društva u cjelini (Gwyter i sur., 2005.). U takvim su situacijama vrijednosti profesije čvrsto uporište na koje socijalni radnici mogu računati, ukoliko su dovoljno razvijene da se njima mogu poslužiti. Kompetencije na toj razini mogu služiti postizanju usklađenosti svih bitnih dionika, najvećoj mogućoj kvaliteti rada te postizanju želja korisnika uz razumijevanje od strane njegove obitelji, zdravstvenog osoblja i društva u cjelini. Vrijednosti koje socijalni radnici trebaju posjedovati su: prepoznavanje i sagledavanje stavova, osjećaja i očekivanja u vezi s bolesti, smrti i sličnim pitanja; pokazivanje poštovanja prema korisnikovim stavovima, snagama i željama vezanima za skrb, kao i stavovima, snagama i željama korisnikove obitelji; osjetljivost i suosjećanje u interakciji s korisnicima i članovima njihovih obitelji; spremnost za rad s ostalim članovima zajednice i interdisciplinarnim timom radi pružanja skrbi, komfornosti i profesionalne ekspertize tijekom kontinuuma bolesti, smrti i žalovanja; filozofija i uvjerenja podudarni s ciljevima timskog rada, uključujući i udobnost 
u upravljanju izazovima u sukobima povezanim s istim; poštovanje i razumijevanje kulturne, jezične, vjerske, duhovne i spolne raznolikosti; poštovanje dostojanstva, povjerljivosti, korisnikove autonomije, vrijednosti i etičkog odlučivanja samog korisnika i njegove obitelji; sposobnost za stvaranje okruženja "podržavajuće nade« i mogućnost pomaganja korisniku i njegovoj obitelji da izraze vlastite strahove, ciljeve i želje s posebnim naglaskom na reagiranje na zabrinutost, strahove, potrebe i nadu; predanost unapređenju psihosocijalnih istraživanja za proširenje činjenične baze vezane uz praksu te povjerljivost i jasnoća uloge socijalnih radnika (Gwyter i sur., 2005.). Socijalni radnik treba posjedovati navedene vrijednosti, raditi u skladu s njima, promicati ih i poticati druge članove tima u palijativnoj skrbi na promicanje ovih vrijednosti i obavljanje prakse u skladu s njima.

\section{Znanje}

Od teorijskog znanja prvenstveno je potrebno posjedovanje znanja o zakonskim regulativama i funkcioniranju medicinskih i socijalnih sustava. Zatim, potrebno je posjedovanje znanja o biopsihosocijalno-duhovnim čimbenicima. To znanje odnosi se na model prema kojem bolest obuhvaća osobu u cjelini - njene biološke, psihološke, socijalne i duhovne dimenzije, a nijedna od tih dimenzije ne može biti izdvojena od drugih (Puchalski i sur., 2009.). Preporuka je da se u svrhu funkcionalnog liječenja procijene i sagledaju svi navedeni aspekti te da se oni uključe u plan tretmana korisnika. Unutar palijativne skrbi postavlja se pitanje tko od članova stručnog tima može procjenom obuhvatiti sve te dimenzije bolesti. Reith i Payne (2009.) navode kako često liječnici i medicinske sestre sakupljaju osnovne podatke o psihološkim, socijalnim i duhovnim dimenzijama korisnika, no detaljno sakupljanje i organiziranje tih podataka ostavljeno je upravo socijalnom radniku. Takva procjena često nadilazi uobičajeno skupljanje anamnestičkih podataka te od socijalnog radnika zahtijeva dublje sagledavanje svih navedenih dimenzija života korisnika, riječ je o upoznavanju života korisnika radi bolje provedbe tretmana. Upravo socijalni radnik, obučen za takvo sagledavanje korisnika, komunicira između dionika palijativne skrbi kako bi biopsihosocijalno-duhovni čimbenici bili valjano uklopljeni u tretman. Socijalni radnik neće korisniku i njegovoj obitelji pristupati kao »dijagnozi« ili »pacijentu«, već će uvidjeti specifičnu životnu priču koja stoji iza njih, odnosno bogato životno iskustvo koje čini podlogu učinkovite prakse socijalnog rada u palijativnoj skrbi. Sljedeća znanja potrebna su radi ostvarivanja ovog temeljnog pristupa (Gwyter i sur., 2005.): znanje o višeznačnosti uloge socijalnog radnika kao kliničara, zastupnika, edukatora, odvjetnika, istraživača, vođe u zajednici i politici; znanje o biološkim, psihološkim, socijalnim, emocionalnim, duhovnim, praktičnim, informativnim i financijskim potrebama i izazovima s koji-

\section{4 članci}




\section{A. Štambuk, T. Obrvan: Uloga, standardi i kompetencije socijalnih radnika u palijativnoj skrbi}

ma se suočavaju korisnik, obitelj i skrbnik, kao i poznavanje načina da se korisnika i obitelj pripremi za smrt u skladu s njihovim kulturnim obilježjima; definicije, ciljevi, vrijednosti i ograničenja različitih opcija njege; poznavanje simptoma, liječenja i utjecaja različitih dijagnoza i psihijatrijskih simptoma na korisnike, obitelji i skrbnike; upravljanje boli i simptomima; poznavanje specifičnih intervencija i terapijskih tehnika koje mogu ukloniti tjeskobu korisnika, obitelji i skrbnika; poznavanje znakova i simptoma skore smrti; vjerske, duhovne i kulturne vrijednosti i očekivanja povezani s bolešću i krajem života, uključujući određene rituale, tabue, vjerovanja i običaje; poznavanje etičkih i pravnih načela; poznavanje obilježja iskustva gubitka, tuge i žalovanja; status lokalnih, državnih i saveznih politika koje utječu na probleme zdravstvenog sustava poput dostupnosti, regulacije i pokrivenosti osiguranjem; resursi zajednice i prakse i način dolaska do njih.

\section{Procjena}

Socijalni radnici svakodnevno procjenjuju potrebe i upravo je procjena ključna vještina u obrazovanju studenata socijalnog rada. Procjena je sagledavanje korisnika tako da se uzmu u obzir sve informacije bitne za razvoj intervencije i planiranje tretmana (NASW, 2004.). Uključenost i procjenjivanje socijalnih radnika u palijativnoj skrbi počinje od napravljene medicinske procjene i procjene zdravstvene njege, ali ima drugačiji fokus od drugih profesija (Reith i Payne, 2009.). Kako je već navedeno, liječnici i medicinske sestre sakupljaju osnovne psihološke, socijalne i duhovne podatke o korisniku tijekom njihovog rada, no sakupljanje i organiziranje koherentnih informacija potrebnih za psihološku i socijalnu procjenu ostavljeno je socijalnim radnicima, pri čemu veliki dijelovi informacija mogu nedostajati. Socijalni radnici planiraju intervencije sa svojim korisnicima upravo temeljem procjene i trebaju biti spremni na stalno preispitivanje i reviziju planova liječenja kao odgovor na novoidentificirane potrebe i promijenjene ciljeve skrbi (NASW, 2004.). Socijalni radnici ne smiju očekivati da će korisnik prilikom prvog susreta izraziti sve želje i potrebe u tretmanu (iako može doći i do takve situacije). Potrebno je održati spremnost i određenu razinu opreza na želje koje korisnik može ostaviti nedorečenima. Stavovi, želje i okolnosti korisnika mijenjaju se kako skrb traje te je stoga permanentna i sveobuhvatna procjena standard koji socijalni radnici trebaju poštovati. U palijativnoj skrbi možemo izdvojiti i druge bitne aspekte nad kojima socijalni radnici trebaju biti sposobni provesti procjenu (Gwyter i sur., 2005.), ali i uvidjeti njihov utjecaj na korisnika i mogućnosti intervencije: fizički, funkcionalni, financijski, socijalni, emocionalni, duhovni i psihološki resursi i podrška te nezadovoljene potrebe; snage, kompetencije i resursi za suočavanje s bolesti i smrti; povijest i potrebe u odnosu na korisnikovu fazu razvoja ili fazu razvoja obitelji te 
životni vijek; struktura, uloge, granice i dinamika obiteljske mreže; kulturna očekivanja, sklonosti te zdravstvena uvjerenja i vrijednosti koje se odnose na pitanja kao što su govorenje istine, napredno planiranje skrbi te percepcija bolesti i liječničkih prognoza; duhovna i/ili vjerska uvjerenja, rituali, vrijednosti i egzistencijalne brige vezane uz skrb na kraju života, upravljanje simptomima, pružanje njege, smrt i umiranje; kvaliteta prošlog i sadašnjeg upravljanja simptomima; obrazovna, praktična i zdravstvena njega, napredno planiranje skrbi, planiranje otpusta, potreba za podrškom i preferencije korisnika po pitanju njege.

Procjena je jedan od osnovnih zadataka socijalnog radnika u timu palijativne skrbi i u radu s korisnikom. Uslijed osnaživanja, a kako bi se poboljšale sposobnosti i odluke korisnika u palijativnoj skrbi, socijalni radnici uključuju procjenu u razvoj i provedbu planova intervencija (NASW, 2004.). Socijalni radnik će izradu i provedbu intervencija raditi temeljem obavljene procjene, sudjelovati u provođenju tretmana, ali i pobrinuti se da sudjelovanje bude omogućeno korisniku i njegovoj obitelji. Planovi tako izrađenih tretmana su napravljeni i revidirani s ciljem da se pronađe rješenje za već identificirane i evoluirajuće potrebe, reagira na promjenjive ciljeve skrbi te poboljša kvaliteta života (Gwyter i sur., 2005.). Procjena igra veliku ulogu i u osnaživanju korisnika. Putem procjene, korisnik dobiva priliku ispričati svoju priču, što je prvi korak u procesu osnaživanja. Procjena podrazumijeva i prepoznavanje osobnih ciljeva, snaga i talenata korisnika, kao i društvene resurse i dostupne sustave podrške u njihovoj zajednici (Kletečki Radović, 2008.). Tako procjena omogućava korisniku da u procesu osnaživanja sagleda sve načine rješavanja problema i izvore pomoći.

\section{Planiranje intervencija i tretmana}

Socijalni radnik izradu i provedbu intervencija radi temeljem obavljene procjene, sudjelovanjem u provođenju tretmana, ali i zalaganjem da sudjelovanje bude omogućeno korisniku i njegovoj obitelji, uzimajući u obzir sve relevantne čimbenike (NASW, 2004.; Gwyter i sur., 2005.). Planovi tako izrađenih tretmana napravljeni su i revidirani s ciljem da se pronađe rješenje za već identificirane i evoluirajuće potrebe, reagira na promjenjive ciljeve skrbi te poboljša kvaliteta života. U planiranju tretmana ključno je da se isti prilagodi pojedincima iz različitih dobnih skupina, etniciteta, kultura, religija, socioekonomskih i obrazovnih pozadina, životnih stilova i varirajućih faza mentalnog zdravlja i oduzetosti, kao i različitim nemedicinskim sustavima te zakonima pojedine zemlje.

Osnovna ishodišta intervencija socijalnog rada u ovom području su: gubitak, nesigurnost te istina, nada i poricanje (Reith i Payne, 2009.). Zbog tako osjetljivih ishodišta intervencija, one će biti specifične. Intervencije mogu uključivati

\section{6 članci}


razne aktivnosti: jačanje komunikacije kako bi se povećala učinkovita i suosjećajna skrb; individualno podržavajuće savjetovanje i integrativne terapije (npr. gestalt terapija); obiteljsko savjetovanje i terapija; učinkovita organizacija, vodstvo i/ili sudjelovanje na obiteljskim ili timskim sastancima, grupnim psihoterapijama, savjetovanjima i psihoedukacijskim intervencijama; vještine koje povezuju korisnike, skrbnike, obitelji, profesionalne zajednice i resurse; integriranje teorija tugovanja u praksu; određivanje prigodnih intervencija temeljenih na procjeni; zauzimanje za potrebe, želje i ciljeve korisnika, pružatelje njege i članove obitelji (NASW, 2004.; Gwyter i sur., 2005.). lako će se svaki socijalni radnik odlučiti za intervencije u kojima je kompetentan i koje odgovaraju situaciji, ipak se može reći da postoje određene osnovne intervencije koje se pružaju u palijativnoj skrbi i s kojima socijalni radnik treba biti upoznat (Gwyter i sur., 2005.): kognitivno-bihevioralne i integrativne intervencije, duhovne intervencije, edukacijske intervencije, okolišne intervencije, krizne intervencije, upravljanje rizikom, rješavanje konflikata, case management intervencije te intervencije povezane s tugom i žalovanjem.

Posebno je važna uloga socijalnog radnika prilikom intervencija usmjerenih kontroli boli i simptoma jer one imaju za cilj omogućiti korisniku dostojanstven kraj života. Socijalni radnici ukazuju na povezanost emocionalnih stanja, percepcija i drugih multidimenzionalnih faktora s kontrolom boli i simptoma te stalno podsjećaju tim da je korisnik onaj koji najbolje poznaje sebe (Cagle i Altilio, 2011.). Socijalni radnik zastupa kontrolu boli i simptoma na način koji će odgovarati korisniku, njegovim vrijednostima i potrebama, a može i sam provoditi određene intervencije kao što su: distrakcija, edukacija, kognitivno-bihevioralna terapija, tehnike opuštanja, vođena fantazija te vođenje »dnevnika boli«.

Socijalni radnik provodi i makrointervencije, odnosno intervencije u zajednici. Reith i Payne (2009.) navode ključne makrointervencije: uključivanje potrebe za prikladnom palijativnom skrbi u javne rasprave i zahtijevanje prikladnih planova skrbi, podrška obiteljima i zajednici u odgovaranju na probleme vezane uz kraj života te postizanje mogućnosti za javno izražavanje iskustva iz navedenog područja.

Evaluacija provedenih intervencija i tretmana socijalnih radnika već je ustaljena u praksi socijalnog rada. Uloga evaluacije je jasna - njome sagledavamo je li socijalni radnik pravodobno i sveobuhvatno odgovorio na potrebe korisnika i obitelji te je li odgovor bio učinkovit (Bosma i sur., 2010.). Socijalni radnik može evaluirati svoje aktivnosti ili aktivnosti tima s korisnicima i obiteljima te izmjenjuje i razvija planove skrbi u skladu s dobivenim informacijama (Bosma i sur., 2008.). U svakom slučaju, kod provođenja evaluacije važno je sudionicima objasniti njenu važnost kako bi što više surađivali i osjećali se što ugodnije tijekom provođenja iste. 


\section{Stav i samosvijest}

Iskazivanjem stava suosjećanja i osjetljivosti s korisnicima, poštujući njihova prava na samoodređenje i dostojanstvo, socijalni radnici istodobno su svjesni vlastitih uvjerenja, vrijednosti i osjećaja te kako njihovo osobno ja može utjecati na njihov rad (NASW, 2004.). Pri tome je socijalni radnik svjestan gdje završavaju njegovi, a počinju osjećaji korisnika, postavlja se u skladu s time i ne dopušta ugrožavanje prakse, istodobno dopuštajući korisniku autonomiju i ravnopravnost. Jedna od bitnih komponenti stava koju bi socijalni radnici u palijativnoj skrbi trebali pokazati je poštovanje korisnikove autonomije. Naime, skrb se pruža samo pod uvjetom da ju korisnik i obitelj žele (Radbruch i Payne, 2009.). Situacija u kojoj korisnik donosi odluku o tretmanu kojem želi biti podvrgnut nije uvijek jednostavna, stručni ga djelatnici informiraju o istome, a socijalni radnik i drugi članovi tima provode intervencije u skladu s time. Ukoliko se socijalni radnici, ali i ostali stručni suradnici u palijativnoj skrbi, nađu u situaciji u kojoj ovlaštena bliska osoba ili obitelj odlučuju o tretmanu, dolazi do etički upitne situacije (Radbruch i Payne, 2009.).

Suosjećanje je jedna od temeljnih vrlina u socijalnom radu u kojoj se kombinira stav aktivnog obzira za tuđu dobrobit s maštovitom svijesti i emocionalnim odgovorom dubokog suosjećanja, nježnosti i nemira zbog tuđe nesreće i patnje (Reamer, 2013.). Suosjećanje pretpostavlja naklonost, ima sličnost s milosrđem i izražava se djelima dobročinstva koja pokušavaju ublažiti nesreću i patnju druge osobe. Za učinkovitu praksu u palijativnoj skrbi bitna je i empatija (NASW, 2004.). To je sposobnost da razumijemo osjećaje, želje, ideje i ponašanja druge osobe te da to razumijevanje i pokažemo. Karakteristika koja empatiju razlikuje od suosjećanja jest to što empatija u sebi ima element svjesnog donošenja odluka, odnosno dobrovoljnog izbora akcije kao odgovora na kognitivnu obradu afektivnog refleksnog odgovora na tuđe osjećaje, što onemogućuje osobi da zauzme perspektivu drugog subjekta u procesu (Gerdes i Segal, 2009.). Empatija pomaže socijalnom radniku razumjeti i djelovati u skladu s često teškim emocijama korisnika, na način kojim će se postići njihova najveća dobrobit, a istovremeno mu omogućava određeno ograđivanje od tih istih emocija, kako bi sačuvao samog sebe od profesionalnog izgaranja.

Prilikom zauzimanja ovog poželjnog i potrebnog stava u palijativnoj skrbi, socijalni radnici su dužni paziti na način i kvalitetu korištenja ovih vještina kako bi se izbjegle negativne posljedice, npr. preuzimanje korisnikovih osjećaja kao svojih ili roditeljsko-zaštitnički odnos (Cournoyer, 2008.). Osjećaji pripadaju korisniku i socijalni radnik ih nema pravo zadržati. Korisnik i njegova obitelj suočeni su sa situacijama bolesti, smrti i gubitka. Socijalni radnik je tu kako bi pokazao suosjećanje i pružio empatiju, ali ne smije doživljavati patnju korisnika kao svoju. S druge strane,

\section{8 članci}




\section{A. Štambuk, T. Obrvan: Uloga, standardi i kompetencije socijalnih radnika u palijativnoj skrbi}

ukoliko uspije razviti ovakav pristup empatiji, ona će mu pomoći da stekne razumijevanje, poštovanje i osjetljivost za korisnike. Takvom vezom s njima povećava se mogućnost razvoja prisnosti i konstruktivne radne veze. Socijalni radnici trebaju posjedovati samosvijest, jednu od komponenti empatije koja je ključna da bi ljudi mogli osjetiti puni opseg empatije. Ona omogućava da čak i, ako postoji određena privremena identifikacija između promatrača i korisnika, ne postoji konfuzija između sebe i drugih. Samosvijest ima još šire značenje, a to je prepoznavanje i razumijevanje vlastitih emocija, prednosti, ograničenja i motiva samospoznaja, odnosno sposobnost da se samorazumijeva, samokontrolira i samovrednuje (Gerdes i Segal, 2009.). Sa samosvijesti je usko povezana samorefleksija čiji je cilj da se unaprijedi praksa na način da se samog sebe sagleda u odnosu na rad u palijativnoj skrbi i prepozna recipročna priroda između sebe i rada (Bosma i sur., 2010.).

\section{Osnaživanje i zastupanje}

Socijalni radnici zagovaraju potrebe, odluke i prava korisnika u palijativnoj skrbi, prisutni su na društvenoj i političkoj sceni tražeći da se uvedu promjene koje omogućavaju jednaki pristup resursima kojima se mogu zadovoljiti biopsihosocijalno-duhovne potrebe korisnika u palijativnoj skrbi (NASW, 2004.). Osnaživanje se odnosi na procese kojima pojedinci, grupe ili zajednice zadobivaju moć, autoritet, pristup društvenim resursima, sposobnost ostvarivanja osobnih ili kolektivnih težnji, odnosno ostvarivanja važnih životnih ciljeva (Kletečki Radović, 2008.). U palijativnoj skrbi riječ je o osnaživanju pojedinaca i njihovih obitelji u tretmanu. Bit osnaživanja je omogućiti pojedincu ili grupi preuzimanje kontrole nad životnim okolnostima, postizanje osobno važnih ciljeva i povećanje sposobnosti za donošenje učinkovitih odluka, dok je ono sastavni dio prakse socijalnog rada, pa čak i kad nije u fokusu neke vrste diskriminacija. Dakle, prilikom osnaživanja bitno je vidjeti ono što je pojedincu važno, bili to životni ciljevi ili određene vrijednosti, svjetonazori i/ ili norme. Osnaživanjem pojedinca utječe se na bolje upoznavanje osobnih potreba, što vodi povećanju osobne moći i sigurnosti u osobne snage, čime se stvara kapacitet za prenošenje utjecaja na druge, a time se otvaraju mogućnosti zadiranja u širi društveni kontekst (Kletečki Radović, 2008.). Kako bi se to postiglo, socijalni radnici u palijativnoj skrbi trebaju posjedovati: predanost promicanju autonomije korisnika; zalaganje za korisnikovo samoodređenje, dostojanstvo, povjerljivost, privatnost i informirani izbor; osjetljivost na obiteljsku, vjersku, kulturnu i etičku raznolikost; znanje o višerazinskim tehnikama zastupanja; znanje o preprekama na koje marginalizirane i ranjive skupine nailaze na kraju života i u procesu žalovanja; svijest o čimbenicima koji ograničavaju mogućnosti zagovaranja; vještine posredovanja, pregovaranja, odlučivanja i olakšavanja; sposobnost prepoznavanja 
i definiranja potreba korisnika i obitelji iz njihove perspektive, a prema njihovih kulturnim i duhovnim uvjerenjima; sposobnost za rad sa sustavima i politikama koje nisu osjetljive na zadovoljavanje potreba korisnika (Bosma i sur., 2008.).

Osnaživanjem se korisnicima daje moć djelovanja na tretman, donošenja vlastitih odluka te iskazivanja vlastitih osjećaja kako bi se postigao što bolji tretman koji, na kraju krajeva, služi da korisnici završe svoj život na način na koji oni to žele. Reith i Payne (2009.) naglašavaju važnost prakse socijalnog rada u osnaživanju jer pomaže korisnicima izgraditi i održati kontrolu nad njihovom životnom situacijom te dopušta svim sudionicima palijativne skrbi izražavanje njihovih priča na njima svojstven način. Socijalni radnik je član tima koji je »zadužen« za osnaživanje korisnika i njegove obitelji. Pri tome je važno krenuti od procjene gdje se korisniku pruža prva prilika da »ispriča svoju priču«. Procjena podrazumijeva i prepoznavanje osobnih ciljeva, snaga i talenata korisnika, kao i društvene resurse i dostupne sustave podrške u njihovoj zajednici te pomaže korisniku sagledati sve izvore podrške i načine rješavanja problema.

Korisnici palijativne skrbi i njihove obitelji spadaju u ranjive skupine koje se često neće moći zauzeti same za sebe (Raymer i Gardia, 2011.). Stoga je zadatak socijalnog radnika koristiti zastupanje radi zadovoljenja biopsihosocijalno-duhovnih potreba korisnika. U palijativnoj skrbi socijalni radnik zastupanje provodi: povezivanjem korisnika s resursima u zajednici, identificiranjem nesrodničke obitelji i pružanje podrške istoj, pomaganjem pojedincima i obiteljima u pregovaranju njihovih ciljeva skrbi, pomaganjem prilikom snalaženja u sustavima koji pružaju skrb korisniku, praćenjem boli i kontrolom simptoma, adresiranjem problema koji se tiču kraja života, sudjelovanjem na timskim konferencijama, savjetovanjem i pružanjem podrške njegovateljima (NASW, 2004.). Raymer i Gardia (2011.) govore o pojmu zastupanja na makro razini koje socijalni radnici mogu raditi tijekom svakodnevne prakse, primjerice: pisanje e-mailova političarima, udruživanje u nacionalne organizacije te sudjelovanje $u$ istraživanjima. Zastupanje na makrorazini ne samo da može postići zadovoljenje potreba korisnika, već stvara sliku o socijalnom radu kao profesiji koja je u mogućnosti politički djelovati i napraviti pozitivnu promjenu. S obzirom na često negativan stav javnosti o socijalnom radu, takvo predstavljanje omogućava i postizanje pozitivne slike profesije u javnosti.

Često zanemareno područje zastupanja jest zastupanje za praksu samu po sebi (Raymer i Gardia, 2011.). Socijalni radnici trebaju zastupati priznatost profesije na području palijativne skrbi te zastupati zakonske promjene u trenutnim financijskim i drugim politikama koje bi mogle obrazovanje socijalnih radnika učiniti dostupnijim (Higgins, 2011.). Također, socijalni radnici trebaju zastupati promjene u politikama koje bi poboljšale zapošljavanje socijalnih radnika.

\section{0 članci}




\section{Vođenje dokumentacije}

Socijalni radnici trebaju dokumentirati sve postupke s korisnikom bilo u njegovim dokumentima ili u liječničkom kartonu, u elektroničkom ili fizičkom obliku (NASW, 2004.). Dokumentacija treba biti provedena u skladu s državnim zakonima, razumljiva i sadržavati sve bitne podatke, kako bi se mogla koristiti i prilikom tretmana u drugim ustanovama. Dokumentacija je bitna u više područja socijalnog rada. U prikupljanju podataka dobivenih procjenom te planiranju tretmana, ona pruža temelj za stvaranje i dostavu kvalitetnih i sveobuhvatnih usluga, olakšava interdisciplinarnu suradnju i koordinaciju usluga, pruža supervizorima oslobađanje od odgovornosti u slučaju sumnje na propuste u superviziji, pruža podlogu za kvalitetnu evaluaciju te samim time pomaže integritetu programa, pruža dokaze o aktivnostima socijalnog radnika u svrhu odgovornosti u određenim situacijama (Reamer, 2005.). lako se u praksi socijalni radnici često žale na preveliku količinu dokumentacije koju vode, ona je prijeko potrebna jer omogućava praćenje tretmana korisnika u slučaju da on promijeni socijalnog radnika ili ustanovu gdje se tretman provodi, služi kao svojevrsna zaštita socijalnom radniku od provedenih tretmana i intervencija, budući da su iste u dokumentaciji objašnjene, opravdane i potkrijepljene dokazima. Kod neprofitnih organizacija vođenje dokumentacije ovisi o broju i vrsti korisnika te može dati legitimitet za potraživanje sredstava. Ovo su samo neki od osnovnih razloga zašto je vođenje dokumentacije bitno. No, ono se nikako ne smije, barem u slučaju palijativne skrbi, svoditi samo na »hladne« podatke o korisniku koji se mogu iščitati iz osnovnih dokumenata. Konstanta dokumentacije službe za socijalni rad treba sadržavati: procjenu, najvažnije probleme, ponuđeni tretman i plan skrbi te osiguravati kontinuitet skrbi, npr. kod premještaja iz bolnice u hospicij ili na kućnu njegu (NASW, 2004.).

\section{Interdisciplinarni timski rad}

S pojmom interdisciplinarnosti i multidisciplinarnosti često se susrećemo u praksi socijalnog rada. Kako je u palijativnoj skrbi bol i kontrola simptoma udružena s biološkim, psihološkim, socijalnim i duhovnim problemima (Reith i Payne, 2009.), vrlo je teško cijeli spektar mogućih potreba korisnika zadovoljiti pristupom samo jedne profesije. Može se reći da palijativna skrb teži pružanju raznih, na početku teško uskladivih usluga, kojima je cilj zadovoljiti sve potrebe, savladati sve probleme i prepreke te pomoći korisniku i njegovoj obitelji u što boljem suočavanju i nošenju s bolesti i krajem života. Quaseem i sur. (2008.) navode kako je jedan od čimbenika koji poboljšava skrb namijenjenu korisniku na kraju života i rad multidisciplinarnih timova koji uključuju medicinske sestre i socijalne službe, 
baš kao i kontinuitet njege, usklađenost usluga i olakšanu komunikaciju. Isto se ostvaruje kvalitetnom komunikacijom među službama i osobama koje su se ranije brinule za korisnika, a za olakšanu komunikaciju od izuzetne su pomoći vještine zagovaranja, pregovaranja i medijacije koje socijalni radnik ima i može iskoristiti za komunikaciju unutar tima te komunikaciju tima s korisnikom. Pokazalo se da je timski rad povoljniji za korisnika (poboljšava njegovo zadovoljstvo, otkriva i ispunjava više korisnikovih potreba i potreba obitelji) te da multiprofesionalni pristup smanjuje ukupan trošak skrbi, skraćuje vrijeme koje korisnici provode u akutnim bolnicama i ima pozitivan učinak na suzbijanje boli i drugih simptoma (Radbruch i Payne, 2009.). Tim sastavljen od više profesija ima bolji uvid u potrebe korisnika, a kvalitetnom komunikacijom može se postići usklađivanje i pružanje njihovih usluga. Kao dio tima palijativne skrbi, socijalni radnici imaju vještine kojima mogu pomoći i poboljšati timski rad na brojne načine (Gwyter i sur., 2005.):

- poticanje učinkovite komunikacije među članovima interdisciplinarnog tima

- poticanje suradnje i multidisciplinarnog obrazovanja

- integriranje i dokumentiranje informacija, zapažanja i prijedloga tima, navođenje odgovornih za provedbu

- premošćivanje napetosti između povjerljivosti korisnika i dijeljenja informacija s timom

- adresiranje načina na koji su korisnik i obitelj informirani o mogućim prognozama i tijeku događaja koji se mogu razviti kako se smrt približava

- konzultacija i zagovaranje u ime korisnika u vezi s biopsihosocijalnim i vjerskim/duhovnim potrebama i vrijednostima korisnika

- poticanje rasprave o etičkim i pravnim pitanjima tijekom bolesti i na kraju života

- podrška članovima tima (pokazujući načine za nošenje sa sukobima i kriznim situacijama, edukacija članova tima o suosjećanju, umoru i sagorijevanju, ukazivanje na važnost interdisciplinarnog obrazovanja u palijativnoj skrbi, pomoć stručnim njegovateljima o religijskim/duhovnim pitanjima, korištenje humora kako bi se ublažilo profesionalno izgaranje).

Osnovni zadaci koje socijalni radnik ima u timu palijativne skrbi već su opisani, a riječ je o procjeni, poticanju kulturološki prilagođene skrbi te planiranju intervencija i tretmana. Uz to, socijalni radnik ima i neformalne uloge: održavanje socijalnih veza poput provođenja pauza s ostalim članovima tima, zajednička druženja članova tima i drugi društveni događaji; pružanje neformalne interpersonalne pomoći članovima tima u svakodnevnim stresorima posla; participacija u »timovima za pacijente«, odnosno timovima koji planiraju rad sa specifičnim korisnikom;

\section{2 članci}


participacija u nošenju s određenim poteškoćama na odjelu, primjerice, pomoć u nošenju s teškim ponašanjem posjetioca ili rodbine korisnika (Payne, 2006., prema Reith i Payne, 2009.). Socijalni radnik u timu palijativne skrbi treba sudjelovati u svim dimenzijama timskog rada: radu s korisnikom, radu s obitelji, planiranju i provođenju tretmana, donošenju odluka, evaluaciji intervencija i tretmana, sudjelovanju u obrazovnim aktivnostima te vođenju dokumentacije.

\section{Kompetencije vezane uz kulturu korisnika i obitelji}

Posjedovanje i razvijanje specijaliziranog znanja i razumijevanja povijesti, tradicije, vrijednosti i obiteljskih sustava koje se odnosi na palijativnu skrb neophodno je socijalnim radnicima (NASW, 2004.). Već je spomenuto da je izuzetno bitno za socijalne radnike prilikom planiranja provođenja intervencija imati na umu određena obilježja korisnika, kao što su pripadnost etničkoj i kulturnoj manjini (Reith $\mathrm{i}$ Payne, 2009.), dob, socioekonomska i obrazovna pozadina te različite faze mentalnog zdravlja i oduzetosti (NASW, 2004.; Gwyter i sur., 2005.). Zbog neizvjesnosti, subjektivnosti, ranjivosti i kompleksnosti situacije u kojoj se korisnik nalazi, socijalni radnik treba biti u stanju razumjeti kulturne i tradicijske zahtjeve korisnika. Socijalni radnici koji razumiju kako kultura utječe na bolest i iskustvo na kraju života pojedinaca i obitelji moći će individualizirati skrb i intervenirati na psihosocijalnoj razini doživljaja bolesti, boli, umiranja i smrti. Stoga socijalni radnici trebaju biti upoznati $s$ praksom i vjerovanjima kulturnih skupina kojima nude kulturno osjetljive usluge (NASW, 2004.). Dean (2001.) sagledava model »manjka kulturnih kompetencija« prema kojemu socijalni radnik priznaje svoju nekompetentnost u kulturi korisnika te daje korisniku (radije nego li sebi) mjesto stručnjaka. Ovakav stav prema kulturnoj kompetenciji može korisnika staviti u položaj moći u odlučivanju, a socijalnog radnika spriječiti da donosi zaključke o korisniku i njegovim željama na osnovi određenih kulturnih obilježja. Možemo zaključiti da je za postizanje kulturne kompetentnosti u palijativnoj skrbi najvažnije biti upoznat s različitim kulturama s kojim se socijalni radnik može susresti, zauzeti stav razumijevanja i učenja prema korisniku i njegovoj kulturi te poštovati kulturnu raznolikost korisnika.

Kako stavovi korisnika prema smrti i umiranju često proizlaze iz njegove kulturne pozadine, zadatak je socijalnog radnika da unutar tima palijativne skrbi potiče kulturološki prilagođenu skrb te se tako otvara prostor za usklađene i prilagođene intervencije u kojima se korisnika sagledava holistički. Razumijevanje kulturnih varijabli i faktora koji posreduju kulturnim utjecajima poput akulturacije, asimilacije i edukacije ključno je za razumijevanje kako pružiti najbolju moguću skrb korisniku i obitelji koji se nalaze pred zahtjevom da donesu značajne odluke u trenucima krize, unutar sustava zdravstvene skrbi koji im je nepoznat i u vremenima koja su zastrašujuća (Borgmeyer, 2011.). 


\section{Trajno obrazovanje}

Palijativna skrb je ubrzano rastuće i promjenjivo polje rada (NASW, 2004.). Riječ je o relativno mladom području još uvijek u razvoju, različitom od države do države, grana se na mnogo teorijskih pravaca i usmjerenja, ali i dolazi u doticaj s mnogim profesijama, prvenstveno pomagačkim. Stoga je potrebno uključiti znanja i vještine palijativne skrbi u obrazovanje, ali i cjeloživotno obrazovanje socijalnih radnika jer će se svi (bez obzira na mjesto rada) prije ili poslije naći u situaciji da rade s korisnikom koji je u situaciji palijativne skrbi ili kraja života. Širenje modela za poslijediplomsko obrazovanje socijalnih radnika naglašava se kao jedan od ključnih prioriteta u socijalnom radu u palijativnoj skrbi (Gwyter i sur., 2005.). Time se postiže veća obrazovanost i stručnost socijalnih radnika u području palijativne skrbi. Cjeloživotnim obrazovanjem socijalni radnici imaju priliku u svoje područje rada donijeti nove vještine, nova znanja i nove kompetencije te na istome pokrenuti promjenu prema modernijem, adekvatnijem pristupu. Također, radeći u timovima palijativne skrbi, socijalni radnik ima mogućnost cjeloživotnog obrazovanja. Ako socijalni radnik propusti tu mogućnost, usklađivanje rada s kolegama iz tima, koji su usvojili najnovije znanje, može biti izuzetno otežano. Ukoliko je dinamika tima narušena, dobrobit korisnika može biti dovedena u opasnost.

\section{Supervizija, vodstvo i trening}

Socijalni radnici kojima je palijativna skrb i skrb na kraju života područje specijalizacije trebali bi voditi obrazovne, supervizijske, administrativne i istraživačke napore s pojedincima, grupama i organizacijama (NASW, 2004.). Supervizija je sveprisutna u socijalnom radu, a njena važnost za socijalni rad potječe od njenog pristupa. Ako se supervizija koristi kao aktivan, kreativan proces uz spremnost na samorefleksiju svih uključenih, ona predstavlja mogućnost za razvoj samopouzdanja i veće stručne kompetencije (Bezić, 2007.). Ona je bitan element koji stručnjacima pomaže u ventilaciji, rješavanju konkretnih problema kao i u osobnom razvoju i postizanju veće kompetitivnosti na polju rada. Svi radnici u palijativnoj skrbi trebali bi prepoznati i kontrolirati svoje emocionalne reakcije na smrt i umiranje (Hughes, Firth i Oliviere, 2015.), a supervizija je alat kojim to mogu postići. Prakticiranjem reflektirajuće praske, socijalni radnici dobivaju znanje o načinima sagledavanja sebe s obzirom na posao, znanje o tome kada i kako dobiti podršku i mentorstvo te znanje o vlastitim snagama, ograničenjima, ranjivostima i potencijalima (Hughes, Firth i Oliviere, 2015.). Na taj način, uz već spomenuto rješavanje konkretnih problema, osobni razvoj i razvoj kompetentnosti, supervizija također pomaže očuvanju mentalnog zdravlja pomagača.

\section{4 članci}




\section{A. Štambuk, T. Obrvan: Uloga, standardi i kompetencije socijalnih radnika u palijativnoj skrbi}

Socijalni radnici trebaju ponuditi superviziju socijalnim radnicima koji rade $u$ praksi, pripravnicima i studentima, kako bi im se osigurala uloga vodećeg stručnjaka u ovom području (NASW, 2004.). Prenošenje stečenog znanja u specijaliziranom području (koje se ne može uvijek steći samo obrazovanjem, nego i praktičnim djelovanjem), izuzetno je bitno za daljnje poticanje interesa mlađih kolega za bavljenje ovim područjem, kao i za postizanje veće kvalitete rada. Iskustveno je znanje ono što u prvom redu razlikuje starije kolege od mlađih te bi se to iskustveno znanje trebalo prenositi u svrhu povećanja kvalitete profesije. Stoga, kad su u mogućnosti, socijalni radnici trebaju zajednički raditi sa studentima socijalnog rada kako bi se zalagali za programe u palijativnoj skrbi te unaprijedili i potaknuli interes za ovu specijalizaciju (NASW, 2004.).

Pod vodstvom se u smislu ovog standarda ne misli na ulogu socijalnog radnika kao »vođe«, bilo u obrazovanju ili radu tima, već kao stručnjaka koji svoje znanje može podijeliti s drugima kako bi oni postali kompetentniji. Vodstvo socijalnog radnika proizlazi iz perspektive koju on zauzima u palijativnoj skrbi, sagledavajući djelovanje raznih faktora na korisnika, u skladu s biopsihosocijalno-duhovnim pristupom. Socijalni radnik na razne načine pomaže voditi aktivnosti tima (Raymer i Gardia, 2011.):

- ukazuje na prirodu patnje korisnika koja se veže uz biološke, psihološke, socijalne te duhovne aspekte kako bi približili model biopsihosocijalnoduhovne skrbi i ostalim profesijama u timu koje mogu biti fokusirane samo na jedan aspekt skrbi

- educira članove tima o različitim tipovima osobnosti klijenata i njihovih obitelji te načinima djelotvorne intervencije pune poštovanja koja može vratiti dostojanstvo u obitelj te zamijeniti bespomoćnost i osudu

- ostvaruje vodstvo kroz djelovanje u široj zajednici, radi poboljšanja rada tima i brige za korisnike i to putem istraživanja mehanizama kojima se može doprijeti do populacija nedovoljno obuhvaćenih palijativnom skrbi te razvijanja partnerstva s udrugama koje okupljaju korisnike oboljele od specifičnih bolesti.

Socijalni radnici trebaju doprinositi istraživačkim inicijativama kako bi demonstrirali djelotvornost profesije i intervencija socijalnog rada kao i da unaprijede priznanje među kolegama drugih profesija o nužnosti rješavanja psihosocijalnih potreba pojedinaca i njihovih obitelji (NASW, 2004.). Sudjelovanje u istraživačkim inicijativama potvrđuje stručnost profesije i sposobnost socijalnih radnika za nošenjem s kompleksnim zahtjevima palijativne skrbi, naglašava komplementarnost socijalnog rada s drugim profesijama koje djeluju na tom području te otvara mogućnosti promjene i usavršavanja profesije. Upravo kroz istraživačke aktivnosti 
socijalni radnici postižu praksu temeljenu na dokazima, koja je nužna za moderan i djelotvoran socijalni rad.

Potrebno je imati na umu da standardi ocrtavaju idealnu sliku socijalnog rada u palijativnoj skrbi. Mogućnost postizanja iste s obzirom na trenutno stanje u praksi palijativne skrbi je upitna. Prvenstveno, socijalni radnici tijekom obrazovanja dobivaju tek osnovna znanja o palijativnoj skrbi putem obaveznih kolegija, a jedan manji dio njih putem izbornih, specifično vezanih za palijativnu skrb. lako sadašnje obrazovanje daje dostatno znanje o ranije navedenim kompetencijama, socijalni radnici nisu upoznati s njihovim specifičnim načinima primjene u palijativnoj skrbi. Uloga socijalnog radnika u palijativnoj skrbi je opširna te se može doživjeti kao homo univerzalis, no u suštini je riječ o profesiji koja povezuje sve pristupe u jedan. S obzirom na raznolike pristupe profesija u palijativnoj skrbi, socijalni radnici služe kao vezivno tkivo, povezujući i usmjeravajući ostale stručnjake kako bi se pružila individualizirana i sveobuhvatna skrb svakom pojedinom korisniku. $U$ ovom radu su standardi i kompetencije obrađeni kao temeljne smjernice za provođenje prakse koje je potrebno postići u što većoj mjeri, ali unutar mogućnosti i ograničenja trenutnog stanja na terenu.

\section{Očuvanje čovjekova dostojanstva - najvažnija zadaća socijalnih radnika u palijativnoj skrbi}

Pomažuće profesije, među koje spada i socijalni rad, duboko zadiru u pitanje ljudskog dostojanstva, odnosno same biti poimanja čovjeka. Tijekom povijesti nije čovjek uvijek bio u centru istraživanja, nego naprotiv, sve vidljivo oko njega. Današnji, suvremeni svijet odlikuje vjera u svemoć znanosti, tehnike i tehnologije. No, unatoč osjećaju »svemoći«, čovjek postaje svjestan svoje ograničenosti i svog otuđenja - od prirode, društva, drugog čovjeka i sama sebe. Uslijed toga, danas se u pomažućim profesijama pojavljuju termini: osobi orijentirana medicina, individualni pristup osobi, holistički pristup čovjeku, totalna bol (koja uključuje fizičku, psihološku, socijalnu i duhovnu bol), interdisciplinarni i multiprofesionalni pristup i drugo. Takvi termini ukazuju na bitno drugačiji pristup čovjeku - uočavanje složenosti čovjekove osobnosti, važnost suradnje, odnosno upućenost čovjeka samog na drugog čovjeka.

Priča o izgubljenom sinu ili priča o milosrdnom ocu (Lk 15, 11-32) ukazuje na samu bit problema s kojim se svakodnevno suočava svaki čovjek, a na poseban način i pomagač. Čovjek je po svojoj prirodi nesavršeno biće, sklono činiti mnogo toga što nije dobro i ne doprinosi njegovom razvoju kao ni razvoju zajednice ni čovječanstva. U traženju sreće i zadovoljstva, čovjek često poseže za ciljevima i

\section{6 članci}




\section{A. Štambuk, T. Obrvan: Uloga, standardi i kompetencije socijalnih radnika u palijativnoj skrbi}

sredstvima koji ga dovode do osiromašenja njega samog, odnosno do još većeg problema, pa čak i do smrti. Čovjek je slobodno biće te ima mogućnost odlučiti se za sreću, život, dostojanstvo, ili odlučiti se za suprotnost svemu navedenome: nesreću, smrt, funkcionalizaciju i manipulaciju čovjekom. Izgubljeni sin (Lk 15, 11-32), tj. nesretni, nezadovoljni sin (nakon što je otišao od očeve kuće i potrošio sve što mu je otac dao), donosi odluku da će se vratiti svome ocu. Dakle, svjesno donosi odluku o promjeni svog ponašanja. Za razliku od sina iz priče, socijalni radnici se često mogu naći u situacijama gdje korisnici ostaju samo na razmišljanju o promjeni svog života, umjesto konkretne promjene. Upravo tu nastupa osnovna uloga socijalnog radnika u palijativnoj skrbi. Slika oca ima preneseno značenje: to je onaj tko pomaže, onaj kome se dolazi po pomoć, ali i onaj u koga se ima povjerenje da može pomoći. Otac ne osuđuje sina, ne tumači mu pravila "pristojnog ponašanja«, ne objašnjava tko je u pravu, a tko u krivu, ne pravi se važan zato jer ima moć odlučiti hoće li ga prihvatiti ili otjerati iz obiteljskog doma. Naprotiv, samo bezuvjetno ljubi, prihvaća i raduje se sinu koji je spoznao da nije na dobrom putu. Ovakav otac trebao bi biti uzor pomažućih profesija, profesija u kojima ljude treba vratiti njihovoj biti - dostojanstvu po kojem jesu ljudi, osnažiti ih da prije svega u sebi pronađu snagu za život i životne promjene, a sebe prihvate kao važne i jedinstvene. Također, ovdje otac svojim ponašanjem pruža primjer sinu kako se i sam treba ponašati. Ako osoba kojoj pomažemo ne osjeti autentičnost u činu pomoći, odnosno da su naše riječi i naša djela dio nas, ta pomoć neće doprijeti do dubina čovjekove ljudskosti, a onda gubi svaki smisao.

U samoj definiciji socijalnog rada istaknuta je važnost osnaživanja i oslobađanja ljudi: "Socijalni rad promiče socijalne promjene, rješavanje problema u međuljudskim odnosima te osnaživanje i oslobađanje ljudi kako bi se povećalo blagostanje. Koristeći teorije ljudskog ponašanja i društvenih sustava, socijalni rad djeluje na mjestima gdje dolazi do interakcije ljudi i njihovog okruženja. Načela ljudskih prava i socijalne pravde su temeljna za socijalni rad« (International Federation of Social Workers, 2000., prema Knežević, Miljenović i Branica, 2013.). Današnje određenje socijalnog rada usmjereno je prema holističkom zahvaćanju pojedinca i društvenih sustava. Jedan od vodećih teoretičara socijalnog rada Payne naglašava da je posao socijalnog radnika da bude $s$ ljudima kao s braćom i sestrama (Joint World Conference on Social Work and Social Development, 2012.). Socijalni rad kao profesija treba imati vrlo jasno istaknuto načelo poštovanja ljudskog bića, njegova dostojanstva kao najvažnije maksime kako u teoriji tako i u praksi. Tomašević (2011.) navodi da su bratstvo i solidarnost osnovni principi kršćanskog utemeljenja principa ljudskog dostojanstva koje na niti jedan način ne može i ne smije biti uvjetovano. Održavanje dostojanstva korisnika u palijativnoj skrbi prelazi religiju i uvjerenja korisnika, ali upravo kršćanska antropologija pruža temelje po kojima 
najjednostavnije možemo usvojiti pojam ljudskog dostojanstva. Čovjek je osoba. Osoba ima egzistencijalnu narav i ne ovisi o dobi, fizičkim ili psihičkim datostima, već o duhovnoj duši koja se nalazi u svakom čovjeku (Ivančić, 2013.). Po njoj se on razlikuje od svih ostalih živih bića. "Vegetativna duša je nositelj vegetativnog života čovjeka, psihička duša je nositelj psihičkog života, a duhovna duša je nositelj duhovnog odnosno čovjekova života koji pripada čovjeku kao osobi« (Ivančić, 2013.: 70). Schockenhoff (2007.) ističe da ukazivanje na tjelesno-duhovno jedinstvo osobe ne počiva na empatijskom preuveličavanju svetosti života niti proistječe iz židovsko-kršćanske tradicije; ono označava antropološki osnovni status ljudske osobe, o kojemu primjereno moraju razmišljati i sekularni (svjetovni) etički nacrti. Nadalje, upozorava da ljudsko dostojanstvo i ljudska prava ne počivaju na kulturalnome pripisivanju koje bi ovisilo o suglasju demokratskoga društva - ljudsko dostojanstvo i ljudska prava, kao i »biti osoba« za svakoga čovjeka proizlaze iz sebe. Bez obzira o kojem je korisniku riječ, starom ili mladom, zdravom ili bolesnom, svjesnom ili nesvjesnom - poštujemo ga samo onda ako ga prihvatimo kao unikatno, neponovljivo i vrijedno biće upravo zbog svoje jedinstvene naravi čovjeka.

Biti čovjek znači prihvatiti život, a prihvatiti život znači prihvatiti i neizbježni dio boli i patnje. Kada govorimo o očuvanju čovjekova dostojanstva, treba reći da ono obuhvaća cjelokupnu kvalitetu čovjeka kao osobe, ali je ono također izvan dosega čovjekove moći. Zahvalnost za dar života čovjek izražava poštujući život, čuvajući ga i unapređujući ga. Također se tu podrazumijeva i borba protiv boli, patnje i prijevremene smrti (Pozaić, 2009.). Odgovor čovjeka, prije svega profesionalca, na patnju i bol drugog čovjeka, treba biti temeljen na poštovanju osnovnog ljudskog dostojanstva što prije svega znači poštovanje prava na život. Stoga je permanentno traženje odgovora za ublažavanje i/ili otklanjanje ljudske patnje važna zadaća svake pomažuće profesije, a posebno profesija koje djeluju u području palijativne skrbi.

Tobin (1999.) ukazuje na nekoliko važnih zadaća koje pomažu u nalaženju mira i dostojanstva na kraju života. Prepoznavanje individualnosti u bolesti i mogućnost osobnog izbora znači pomoći korisniku da razlikuje osobu od dijagnoze (»/mam dijagnozu kao mnogi drugi, ali ja nisam oni. Ja sam ja, jedinstven, unikat. Mogu odabrati ono što ja želim, imam svoj put.«) Nadalje, potrebno je omogućiti osobi da preuzme kontrolu nad vlastitim životom, odnosno da se suoči sa strahom od umiranja. Prema Eriksonovoj psihosocijalnoj teoriji (Erikson, 2008.), uspješni prijelazi kroz razvojne stadije života vode sintezi koja može biti osnova za razvoj prema zadnjem stadiju - starosti. U ovoj fazi pojedinac može imati osjećaj integriteta ili očaja, a karakterizira ju procjena cjelokupnog vlastitog života. Ukoliko je pojedinac uspješno riješio ranije krize te u svom životu otkrio smisao i red, on tada postiže osjećaj cjelovitosti, unutrašnje jedinstvo ličnosti, odnosno integritet

\section{8 članci}


ega. Vrednota koja proizlazi iz ove faze je mudrost. Ako se ne dostigne integritet i ne otkrije smisao svega što smo u životu napravili (uspjeha i neuspjeha), prijeti nam osjećaj promašenosti, beznađa, depersonalizacije, straha, depresije i očajanja pred skorom smrću. Kada osoba prevlada strah od umiranja, postaju važne vlastite potrebe i želje. Stoga osobu treba poticati da ih osvijesti i izrazi te da joj se pomogne u njihovoj realizaciji. Naša profesionalnost treba biti na dobrobit onih kojima pomažemo kako bi kroz realizaciju osobnih potreba imali kontrolu nad vlastitim životom. Razgovor o bolesti i njenoj prognozi te suočavanje s realnošću još je jedan od preduvjeta u očuvanju dostojanstva. Osoba ima pravo znati sve informacije koje ju zanimaju o bolesti, njenim manifestacijama i mogućnostima liječenja. Razumijevanje posebnosti vezanih za bolest i njenu prognozu može pomoći osobi kao i članovima njene obitelji u planiranju bliske budućnosti. Upravo održavanje bliskosti s važnim osobama za umirućeg je izuzetno važno kako bi se što lakše nosio s dolaskom smrti. Da bismo kao pomagači mogli razgovarati o teškim bolestima, moramo se suočiti s vlastitom smrtnošću i prihvatiti ju. Stoga je od izuzetnog značaja iskrenost spram vlastitih misli i osjećaja, sposobnost istovremene svjesnosti istih te donošenje odluke o pravoj intervenciji. Duhovni pogled na življenje i umiranje izuzetno je važan segment u očuvanju dostojanstva. Duhovnost osobe je bitna tijekom cijelog života, a posebno u trenucima umiranja. Ona predstavlja razumijevanje i odnos umirućeg s višom silom kao izvorom smisla, nade i opraštanja. Opraštanje pruža toliko mnogo, uključujući i onaj osjećaj potpunosti za koji smo bili sigurni da nam ga je trajno uzeo onaj koji nas je uvrijedio. Jednom kada oprostimo drugima i sebi, vraćamo se na mjesto milosti, vraćamo se svom bitku. Oprostiti znači nadići pogrešku, radi čovjeka. Upravo nas umirući mogu naučiti istinskom oprostu, jer zapravo ukazuju na prihvaćanje osobe, a otpuštanje i odbacivanje njenih loših čina. Duhovnost podrazumijeva smirenje zbog otkrivanja smisla proživljenog života i dolazeće smrti. Jedno od ključnih pitanja umirućeg i njegove obitelji je gdje dočekati smrt - gdje umrijeti? Bitno je u ovom pitanju poštovati odluku umirućeg jer već sam odabir mjesta umiranja za umirućeg nešto znači - sigurnost, udobnost, komoditet, ljubav bližnjih, pažnju, brzu medicinsku pomoć, izvrsnu njegu i tome slično. Vlastiti dom, bolnica, hospicij, domovi za njegovanje su mjesta gdje se mogu ostvariti gore navedeni uvjeti, no u svakom od njih prevladava tek nekoliko od navedenih uvjeta. Neovisno o mjestu koje osoba odabere za umiranje, važno je osigurati prevenciju boli i izolacije. Postoji mnogo načina kako se bol može kontrolirati. $U$ te svrhe najviše se koriste preparati kod čije primjene se nastoji postići ravnoteža kako bi se pacijentu osigurala svjesnost i maksimalno smanjenje patnje. Svakako treba voditi brigu o svim aspektima boli uvažavajući termin totalna bol. Nalaženje konačnog mira svake umiruće osobe zadnji je izazov u radu profesionalaca koji rade s umirućima i njihovim obiteljima. $U$ 
dolasku do tog mira najviše pomaže sjećanje na ljubav koju je umirući u svom životu imao prilike primiti i dati bliskim osobama, prisustvo upravo tih osoba u vremenu umiranja, izražavanje svoje ljubavi i zahvalnosti svakoj od tih važnih osoba, ali i razrješavanje konfliktnih odnosa, otpuštanje osjećaja krivnje i žaljenja za nečim što je davno učinjeno. Ukoliko osoba uz suradnju svojih najbližih i profesionalaca uspije ispuniti svoje želje i potrebe te se uspije mirno oprostiti od svojih najmilijih, ona postiže mir u svojim mislima i osjećajima i spremna je otići. Siegel (2012.) navodi da kada ljudi postignu mir sa sobom i drugima - postaje im u redu umrijeti, »opustiti se i uživati«. Nasuprot ovome, rastegnuta, živa smrt događa se kada se osjećaji ne izgovaraju, sukobi ostaju nerazriješeni, a život ide dalje samo zbog drugih.

\section{Skrb o vlastitom dostojanstvu i dostojanstvu korisnika - ključ kompetentnosti i standarda u palijativnoj skrbi}

Svjesnost o vlastitom dostojanstvu trebala bi biti baza, odnosno polazište svakog našeg djelovanja. No, ključno je pitanje jesmo li u svojoj profesionalnoj edukaciji imali prilike ne samo naučiti što je to dostojanstvo ljudske osobe, nego i osvijestiti vlastito dostojanstvo i njegovati ga. Jer kako ćemo znati prepoznati nešto čega sami nismo svjesni? Kada netko voli ono što radi, on vidi smisao svoga rada, tj. vidi puno više od samog posla - to znači imati poziv. A kada smo pozvani, ne radimo zbog plaće i priznanja, nego slijedimo poziv. To je kao igra u kojoj smo potpuno predani, zaigrani. Stoga ćemo za nekoga tko voli ono što radi reći da daje sebe. Davati sebe znači dotaknuti drugoga i prepoznati sebe u drugome. To također znači vjerovati da u drugome postoji potencijal koji on trenutno nije svjestan ili je prekriven boli, patnjom, neznanjem, siromaštvom. Biti profesionalac koji pomaže umanjiti patnju i bol - znači svakodnevno otkrivati i upućivati na snagu koja se nalazi u odabiru dobrog $\mathrm{i}$ istinitog, odnosno u odabiru dostojanstva.

Kao što je to slučaj s pojmom kvalitete života u palijativnoj skrbi, čini se da je i dostojanstvo individualan koncept koji za svakog uključuje različite domene i prioritete. Ovisno o definiciji, dostojanstvo se može vidjeti više kao inherentno svojstvo, nego kao predmet koji se može oštetiti ili izgubiti (Chochinov, 2012.). Autor govori o faktorima koji pomažu očuvanju dostojanstava, a odnose se na područje perspektiva i praksu. Perspektive se odnose na pogled na svijet, odnosno vlastiti način suočavanja sa životnim događajima ili okolnostima. U perspektive spadaju: očuvanje doživljaja sebe (iako sam bolesna, to sam i dalje ja), zadržavanje socijalnih uloga (iako sam bolesna, i dalje sam sestra, majka, domaćica, prijateljica...), trag ili nasljedstvo (iako sam bolesna, želim da me zapamtite po npr. specifičnom smislu za humor), zadržavanje ponosa (očuvanje samopouzdanja), nada, autonomija ili kontrola (opseg radnji koje osoba može samostalno obavljati), prihvaćanje 
promjene (prilagodba na promjene u zdravlju) i borbeni duh (unutarnja snaga za suočavanje sa izazovima koji su ispred nas). Praksa koja pomaže u očuvanju dostojanstva odnosi se na ponašanja ili aktivnosti koje omogućavaju osobi da se nosi s promjenama u životnim okolnostima. Tu spadaju: sposobnost življenja u trenutku (za mene postoji ovdje i sada - ova praksa omogućava ljudima da se koncentriraju na sadašnji trenutak i ne gledaju u budućnost koja je neizvjesna), zadržavanje svakodnevice (obavljanje svakodnevnih poslova i uobičajenih rutina) te traženje duhovne utjehe. Navedeni faktori mogu biti polazišna točka socijalnom radniku u radu s korisnicima imajući u vidu jedinstvenost svake osobe, odnosno individualiziran pristup.

\section{Očuvanje dostojanstva u patnji}

Primjeri u kojima je bolest dovela do preobražaja života poznati su mnogim liječnicima, zdravstvenim i nezdravstvenim profesionalcima ili duhovnim učiteljima, kao i običnim ljudima. Autor knjige »Ljubav, medicina, čuda« Bernie Siegel (2012.) navodi da se sustavi vjerovanja liječnika i pacijenta međusobno prožimaju, no tijelo pacijenta izravno reagira na vlastita uvjerenja. Vjerojatno je, navodi autor, da će liječnik, kada iscrpi sva svoja sredstva, odustati. Stoga nikada ne smijemo reći: »Više ništa ne mogu učiniti za Vas«. Sasvim je moguće da su uobičajene prognoze koje liječnici daju pacijentima u tome koliko im je vremena preostalo, nepotrebne. Svaki pacijent trebao bi biti suglasan s idejom da može ozdraviti, bez obzira na to kolike mu šanse drugi daju. Kao profesionalci trebamo vjerovati s osobom u oporavak i izlječenje. Najbitnije što čovjeku treba za ozdravljenje nalazi se unutar njega samoga - mi mu samo trebamo pomoći da to u sebi pronađe. Taj dio u nama zna što nam treba, a to je zdravlje i život. Kada to prihvatimo, neće nas biti briga što drugi misle, čak i kada misle da smo ludi. lako se može raspravljati o adekvatnosti takvog pristupa i moguće »lažne nade« koju on može donijeti korisnicima, moramo se zapitati: što je blagotvornije za korisnika palijativne skrbi - da provede zadnje dane u nadi ili u očaju?

Bol i patnja jesu zadaće koje nam život postavlja da na njima rastemo. Mnoge bolesti - doživljene i izdržane - dovode do novog čovjeka, do preobražaja života. Stoga nelagodnost, bol i patnja što ih donosi bolest, ili patnja bilo koje vrste, imaju izazovni i potencijalni karakter da se podnesu i svladaju te da se krene na novi način od početka. Jores (1982.) ukazuje da bolest ima svoj zahtjevni karakter, ona je signal za preispitivanje sebe, svog ponašanja prema ljudima i svog života. Peck (2013.) govori da bolest i simptomi nisu ista stvar. Naime, bolest postoji prije simptoma, a oni su vanjski znak da nešto nije u redu - oni su znak da nešto trebamo promijeniti. Peck ide i korak dalje te navodi da su oni proizvod »moćne sile« koja 
potječe izvan ljudske svijesti i potpomaže duhovno sazrijevanje, a onda i put u ozdravljenje. Bolesnom čovjeku treba posredovati zdravlje. U tome nas treba voditi princip ljubavi, bratstva i zajedništva, a posebno treba voditi brigu oko njegovanja realne nade.

\section{ZAKLJUČNA RAZMATRANJA}

Umiranje nije smrt, ono je krajnji dio života i treba ga proživjeti dostojanstveno. Kako bismo osobi koja prolazi kroz ovo iskustvo života pomogli u tome, potrebno je uvažavati njezine želje, potrebe i interese, a u tome ključnu ulogu ima i socijalni radnik.

Očuvanje dostojanstva čovjeka, odnosno očuvanje života u svoj njegovoj punini do same smrti, treba biti najveći profesionalni izazov socijalnog radnika i drugih profesionalaca u palijativnoj skrbi. Znanjem i iskustvom, ali prije svega etičkim pristupom i stalnom izgradnjom vlastite osobnosti, profesionalci trebaju biti donositelji mira onima koji odlaze jednako kao i onima koji ostaju. Zadaća je to puna odgovornosti, ljepote i zanosa - zadaća biti čovjek koji transcendira sebe!

Kako bismo tu zadaću ostvarili, potrebno je poznavati standarde svoje profesije, kako bismo istu obavljali savjesno i kvalitetno. Potrebno je poznavati koje su kompetencije potrebne, kako bismo osvijestili sebi što imamo, ali i ono što nam je još potrebno da budemo što bolji profesionalci. Navedena uloga, standardi i kompetencije socijalnih radnika kao i filozofija palijativne skrbi kroz biopsihosocijalnoduhovni pristup trebaju pridonijeti razvoju profesije socijalnog rada u palijativnoj skrbi u Hrvatskoj.

\section{LITERATURA}

1. Bezić, I. (2007). Supervizija kao način razvijanja samopouzdanja i sposobnosti podnošenja konfrontacije. Ljetopis socijalnog rada, 14 (2), 443-452.

2. Borgmeyer, T. (2011). The social work role in decision making: Ethical, psychosocial, and cultural perspectives. In: Altilio, T. \& Otis-Green, S. (eds.), Oxford textbook of palliative social work. New York: Oxford University Press, 615-624.

3. Bosma, H., Johnston, M., Cadell S., Wainwright, W., Abernathy N., Feron, A., Kelley M. L. \& Nelson, F. (2008). Canadian social work competencies for hospice palliative care: A framework to guide education and practice at the generalist and specialist levels. Preuzeto s: http://www.chpca.net/media/7868/Social_Work_ Competencies_July_20 09.pdf. (3.7.2014.)

\section{2 članci}


4. Bosma, H., Johnston, M., Cadell, S., Wainwright, W., Abernethy, N., Feron, A., Kelley, M. L. \& Nelson, F. (2010). Creating social work competencies for practice in hospice palliative care. Palliative Medicine, 24 (1), 79-87.

5. Business Dictionary (2014). Preuzeto s: http://www.businessdictionary.com/. (5.7.2014.).

6. Cagle, J. G. \& Altilio, T. (2011). The social work role in pain and symptom managemet. In: Altilio, T. \& Otis-Green, S. (eds.), Oxford textbook of palliative social work. New York: Oxford University Press, 271-286.

7. Chochinov, H. M. (2012). Dignity therapy - Final words for final days. Oxford: Oxford University Press.

8. Cournoyer, B. R. (2008). The social work skills workbook. Belmont: Thomson Brooks/Cole.

9. Dean, R. G. (2001). The myth of cross-cultural competence. Families in Society: The Journal of Contemporary Social Services, 82 (6), 623-630.

10. Erikson, E. H. (2008). Identitet i životni ciklus. Beograd: Zavod za udžbenike.

11. Forte, A. L., Hill, M., Pazder, R. \& Feudtner, C. (2004). Bereavement care interventions: A systematic review. BMC Palliative Care, 3 (3), 20.

12. Gerdes, K. E. \& Segal, E. A. (2009). A social work model of empathy. Advances in Social Work, 10 (2), 114-127.

13. Glajchen, M. (2011). Caregivers in palliative care: Roles and responsibilities. In: Altilio, T. \& Otis-Green, S. (eds.), Oxford textbook of palliative social work. New York: Oxford University Press, 223-233.

14. Gwyter, L. P., Altilio, T., Blacker, S., Christ, G., Csikai, E. L., Hooyman, N., Kramer, B., Linton, J. M., Raymer M. \& Howe, J. (2005). Social work competencies in palliative and end-of-life care. Journal of Social Work in End-of-Life \& Palliative Care, 1 (1), 87-120.

15. Harding, R. \& Leam, C. (2005). Clinical notes for informal carers in palliative care: Recomendations from a random patient file audit. Palliative Medicine, 19 (8), 632-642.

16. Higgins, P. C. (2011). Guess who's coming to dinner? The emerging identiy of palliative social workers. In: Altilio, T. \& Otis-Green, S. (eds.), Oxford textbook of palliative social work. New York: Oxford University Press, 31-40.

17. Hughes, S., Firth, P. \& Oliviere, D. (2015). Core competencies for palliative care social work in Europe: An EAPC white paper - part 2. European Journal of Palliative Care, 21 (6), 38-44.

18. Ivančić, T. (2013). Hagioterapija u susretu s čovjekom. Zagreb: Teovizija.

19. Joint World Conference on Social Work and Social Development (2012). Preuzeto s: http://www.theguardian.com/social-care-network/2012/jul/11/social-worksocial-policy-conference. (5.7.2014.).

20. Jores, A. (1982). Čovjek i njegova bolest. Zagreb: Biblioteka oko tri ujutro. 
21. Kletečki-Radović, M. (2008). Teorija osnaživanja u socijalnom radu. Ljetopis socijalnog rada, 15 (2), 215-242.

22. Knežević, M., Miljenović, A. \& Branica, V. (2013). Teorija socijalnog rada. Zagreb: Pravi fakultet, Studijski centar socijalnog rada, Biblioteka socijalnog rada.

23. McMillan, S. C., Small, B. J., Weitzner, M., Schonwetter, R., Tittle, M., Moody, L., \& Haley, W. E. (2006). Impact of coping skills intervention with family caregivers of hospice patients with cancer. Cancer, 106 (1), 214-222.

24. Mulkerin, C. M. (2011). Palliative care consultation. In: Altilio, T. \& Otis-Green, S. (eds.), Oxford textbook of palliative social work. New York: Oxford University Press, 43-51.

25. National Association of Social Workers (2004). NASW standards for palliative and end-of-life care. Preuzeto s: http://www.socialworkers.org/practice/default.asp. (17.8.2014.).

26. Parry, J. K. (2001). Social work theory and practice with the terminaly ill (2nd edition). New York: The Haworth Social Work Practice Press.

27. Peck, M. S. (2013). Put kojim se rjeđe ide. Zagreb: Mozaik knjiga.

28. Pozaić, V. (2009). Palijativna skrb i ljudsko dostojanstvo bolesnika. Glasnik pulske bolnice, 6 (6), 121-123.

29. Puchalski, C., Ferrel, B., Virani, R., Otis-Green, S., Baird, P., Bull, J., Chochinov, H., Handzo, G., Nelson-Becker, H., Prince-Paul, M., Pugliese, G. \& Sulmasi, D. (2009). Improving the quality of spiritual care as a dimension of palliative care: The report of the consensus conference. Journal of Palliative Medicine, 12 (10), 885904.

30. Quaseem, A., Snow, V., Shekelle, P., Casey, D. E., Cross, J.T. \& Owens, D. K. (2008). Evidence-based interventions to improve the palliative care of pain, dyspnea, and depression at the end of life: A clinical practice guideline from the american college of physicians. Annals of Internal Medicine, 148 (2), 141-146.

31. Radbruch, L. \& Payne, S. (2009). White paper on standards and norms for hospice and palliative care in Europe: part 1. European Journal of Palliative Care, 16 (6), 278-289.

32. Raymer, M. \& Gardia, G. (2011). Enhancing professionalism, leadership, and advocacy: A call to arms. In: Altilio, T. \& Otis-Green, S. (eds.), Oxford textbook of palliative social work, New York: Oxford University Press, 683-687.

33. Reamer, F. G. (2005). Documentation in social work: Evolving ethical and riskmanagement standards. Social Work, 50 (4), 325-334.

34. Reamer, F. G. (2013). Social work values and ethics. New York: Columbia University press.

35. Reith, M. \& Payne, M. (2009). Social work in end-of-life and palliative care. Chicago: Lyceum Books, inc. 
36. Schockenhoff, E. (2007). Koliko je nedodirljivo ljudsko dostojanstvo? Veza između ljudskoga dostojanstva, osobe i naravi na području bioetike. Bogoslovska smotra, 77 (1), 5-21.

37. Sheldon, F. M. (2000). Dimensions of the role of the social worker in palliative care. Palliative Medicine, 14 (6), 491-498.

38. Siegel, B. (2012). Ljubav, medicina, čuda - pouke o samoizlječenju iz iskustva kirurga s iznimnim pacijentima. Zagreb: Krijesnica.

39. Štambuk, A. (2011). Some components of quality of life in palliative care. U: Buljevac, M., Leutar, I., Štambuk, A., Shank, B. W. \& Leutar, Z. (ur.), Zbornik radova Međunarodne znanstvene konferencije "Socijalni rad $i$ borba protiv siromaštva $i$ socijalne isključenosti - profesionalna usmjerenost zaštiti $i$ promicanju ljudskih prava«. Zagreb: Zaklada Marija de Mattias, 337-356.

40. Štambuk, A. (2013). Uloga socijalnog radnika u palijativnoj skrbi. U: Brkljačić, M., Šamija, M., Belev, B., Strnad, M. \& Čengić, T. (ur.), Palijativna medicina. Rijeka: Markulin, d.o.o., 48-53.

41. Tobin, D. R. (1999). Peaceful dying. Cambridge, Massachusetts: Perseus books.

42. Tomašević, L. (2011). Teološki pogled na dostojanstvo ljudske osobe. U: Jurišić, H.G. (ur.), Kačić - Zbornik u čast Emilija Marina god. XLI.-XLIII. Split: Franjevačka provincija Presvetog Otkupitelja, 1165-1196. 
Ljetopis socijalnog rada 2017., 24 (1), 119-146.

Ana Štambuk

University of Zagreb

Faculty of Law

Department of Social Work

Tamara Obrvan

Home for the elderly »Centar"

\section{THE ROLE, STANDARDS AND COMPETENCIES OF SOCIAL WORKERS IN PALLIATIVE CARE}

\section{ABSTRACT}

Social changes across the world have led to an increased need for palliative care. This approach encourages interdisciplinary team work and creates productive ground for the development of social work as a profession. The first step is to establish key standards and competencies that confirm the need for the profession of social work and support its growth. Social workers have the knowledge, skills and competencies needed to work in different domains of palliative care, which are built into the role of a social worker in the comprehensive approach of palliative care. In view of the contemporary theoretical concepts, basic tenets of social work practice and palliative care, and skills and competencies of social workers, a guide for social workers working in palliative care has been drawn up which could help them in their work in this relatively new field of practice. This paper presents the basic standards and competencies, as well as the role of social workers in palliative care as the basis for their further development.

Key words: palliative care, social workers, standards, competencies, role.

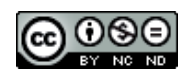

Međunarodna licenca / International License:

Creative Commons Attribution-NonCommercial-NoDerivatives 4.0.

\section{6 članci}

